\title{
Physiological and Ecological Characteristics, and Control of The Perennial Weed Torpedograss (Panicum repens L.) in Crop Field and Turf in Ryukyu Islands, Japan
}

\author{
Md. Amzad Hossain*
}

Key words: perennial weed biology, plant growth response to edaphic factors, rhizomatous weed control, usages of torpedograss, weed-crop interaction.

\section{Introduction}

Studies on the physiology, biology and ecology of a plant species are very important for understanding its management practices and possible usages. Rhizomatous weeds are the most difficult to control due to their vegetative reproduction by underground propagules. Rhizomes and/or tubers of a plant species remain dormant in different soil layers for several years, which is one of the factors for survival of the species. The plants adapting to variable climatic and edaphic factors are difficult to control because they modify their morphological characteristics with the environments, and they are resistant to herbicides. Torpedograss (Panicum repens L.), a rhizomatous perennial plant, grows in tropical and subtropical regions (lat $35^{\circ} \mathrm{S}$ to $43^{\circ} \mathrm{N}$ ) around the world. It is found in lowland coastal areas as well as local inland areas to elevations of 1500 to $2000 \mathrm{~m}$. Torpedograss is a serious weed in various crop fields, orchards and golf courses and reduces plant yield up to $80 \%$. It also invades ditches, drains, watercourses, fishponds, and floating mats of vegetation from banks and

\footnotetext{
${ }^{*}$ Subtropical Field Science Center, Faculty of Agriculture, University of the Ryukyus, Okinawa, 903-0213 Japan (2005年 3 月 22 日受理)
}

adjacent areas. No crop field or golf course in the Ryukyu Islands (Okinawa, Japan) is free from torpedograss infestation, and sugarcane, the main crop in Okinawa covering $50 \%$ of cultivable lands, is severely infested with this weed. No comprehensive control strategy of torpedograss has yet been developed. This paper presents physiological and ecological characteristics, and control strategies of torpedograss in crop (sugarcane) field and turf in the Ryukyu Islands. In addition, possible usages of torpedograss are discussed based on biological and ecological aspects of this plant.

\section{Results and discussion}

\section{Germination and emergence response of torpedograss to climatic and edaphic factors}

Torpedograss is regenerated mainly by rhizomes and to some extent by stems, but not by seeds. Torpedograss produces infertile seed all year round. Germination of the rhizome buds of torpedograss was $100 \%$ at temperatures of 20 to $35^{\circ} \mathrm{C}$, but germination was not observed at extremely low and high temperatures $\left(<5^{\circ} \mathrm{C}\right.$ and $>45^{\circ} \mathrm{C}$ ). Torpedograss shoots emerged well in soil with a $\mathrm{pH}$ range of 4 to10. Torpedograss shoots emerged from the rhizomes at up to 50 cm depth in dark-red soil (Fig. 1). About 95\% of the emerged shoots of torpedograss were recorded 60 days after land preparation, and $91 \%$ emergence was obtained from the upper $20 \mathrm{~cm}$ soil layer. Reduction of moisture in torpedograss 


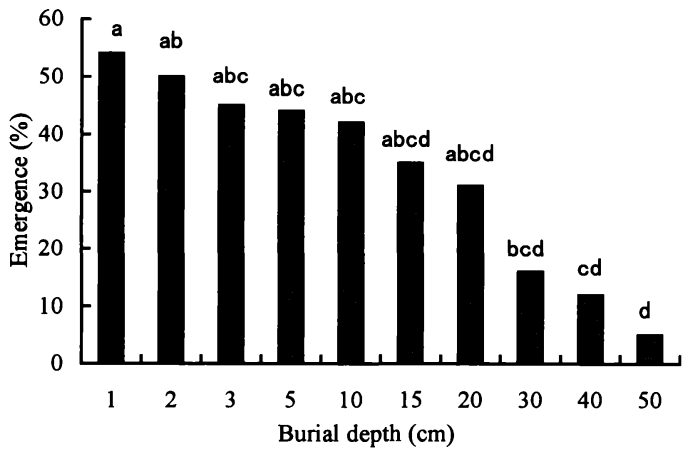

Fig. 1 Effect of burial depth on emergence of torpedograss. Bars with the same letters are not significantly different at the $5 \%$ level, as determined by LSD test.

rhizome from $66 \%$ to $7 \%$ resulted in $0 \%$ bud sprouting (Table 1).

\section{Growth characteristics of torpedograss as influenced by climatic and edaphic factors, and fertilizer application}

Above-ground shoots of torpedograss grew slowly until 50 days after planting (DAP); thereafter, they increased rapidly with time (Fig. 3). The main rhizomes developed at around 50 DAP. Primary branches of rhizomes developed at around $70 \mathrm{DAP}$, and secondary ones at 110 DAP (Fig. 4). Growth and development of rhizomes were always faster than that of aboveground shoots. Rhizomes and roots made a loose mat-like structure into soil up to $50 \mathrm{~cm}$ deep. One plant from a single rhizome-bud produced
24,000 rhizome buds and covered $9 \mathrm{~m} 2$ in a year. Total biomass production increased with time in spite of decreased temperature (Figs. $2,5)$. Three growth phases were identified: establishment growth phase (up to 70 DAP), moderate growth phase (70 to110 DAP) and

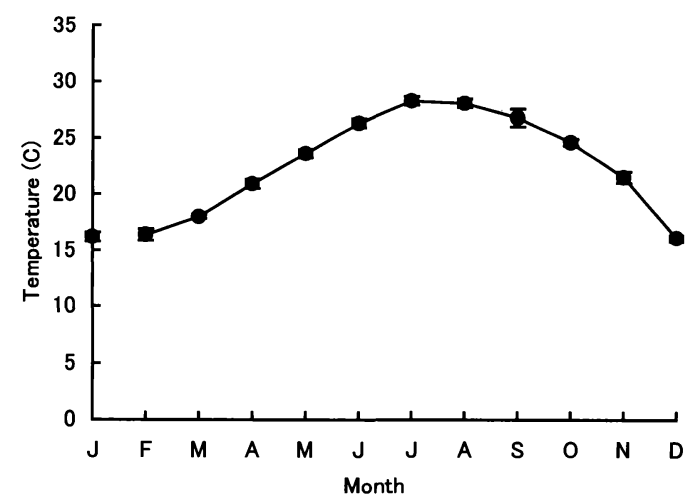

Fig. 2 Mean monthly ambient temperature in the experimental region during 1993-2001.

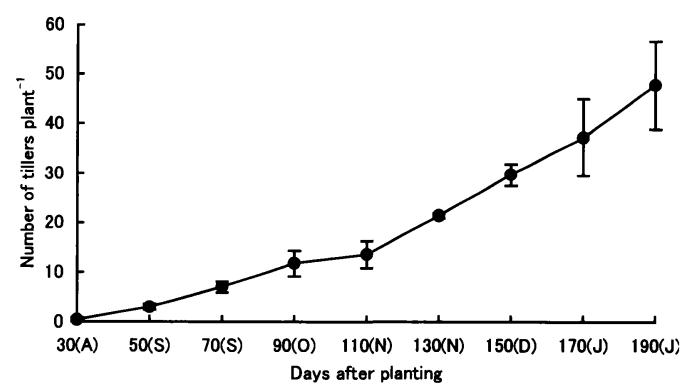

Fig. 3 Changes in number of torpedograss tillers over time. Data are means $\pm \mathrm{SD}$ of five replications. Data were taken from August 1993 to January 1994.

Table 1. Rhizome bud sprouting of torpedogrss as influenced by water content in rhizome.

\begin{tabular}{cccc}
\hline $\begin{array}{c}\text { Water content } \\
\text { in rhizome (\%) }\end{array}$ & $\begin{array}{c}\text { Duration of } \\
\text { drying (hours) }\end{array}$ & $\begin{array}{c}\text { *Water recovery in } \\
\text { rhizome (\%) }\end{array}$ & $\begin{array}{c}\text { Rhizome bud } \\
\text { sprouting (\%) }\end{array}$ \\
\hline $54-66$ (fresh rhizome) & 0 & $54-66$ & 100 \\
$42-53$ (dry rhizome) & 24 & $52-61$ & $64-100$ \\
$32-41$ (dry rhizome) & 48 & $47-60$ & $56-90$ \\
$11-20$ (dry rhizome) & 72 & $45-55$ & $27-31$ \\
6-9 (dry rhizome) & 96 & $41-51$ & $10-13$ \\
5-7 (dry rhizome) & 120 & $41-50$ & 0 \\
\hline
\end{tabular}

${ }^{*}$ Rhizomes were soaked with water for 16 hours.

\# Data were taken from 161-192 buds (creeping and ginger-like rhizomes) for each treatment. 


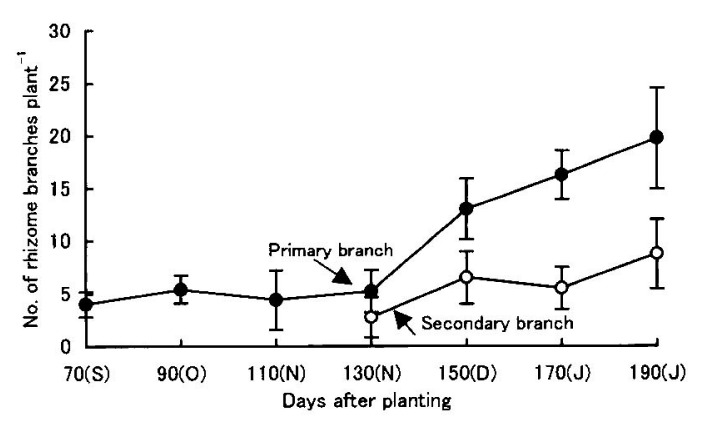

Fig. 4 Changes in rhizome branches of torpedograss over time. Data are means $\pm \mathrm{SD}$ of five replications. Data were taken from September 1993 to January 1994.

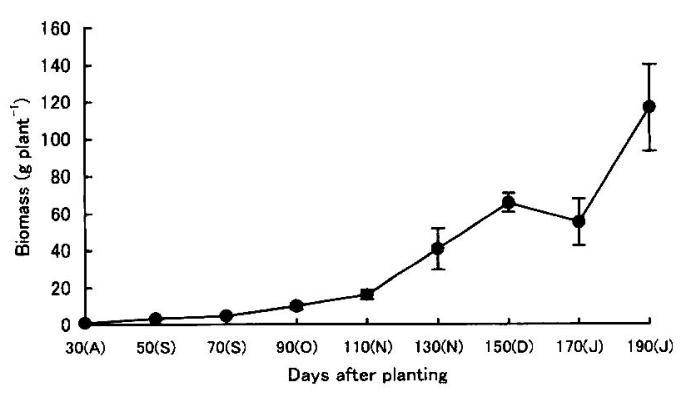

Fig. 5 Biomass production of torpedograss with time. Data are means $\pm S D$ of five replications. Data were taken from August 1993 to January 1994.

fast growth phase (110 DAP to last harvest). Torpedograss shoots elongated up to $150 \mathrm{~cm}$ in field conditions, but can elongate up to 250 $\mathrm{cm}$ when optimum moisture, temperature and nutrients are available.

Creeping rhizomes and ginger-like rhizomes were found in torpedograss. The creeping rhizomes had internodes with a hollow medullary cavity, and each node had a single bud. The ginger-like rhizomes were solid, swollen, knotty, and ginger rhizome-like in shape. Every gingerlike rhizome had one or more buds depending on size and age (Fig. 6). Ginger-like rhizomes developed from the shoot base, and creeping rhizomes developed from the ginger-like rhizomes. Creeping rhizomes elongated more than $6 \mathrm{~m}$, and the tip of the creeping rhizome
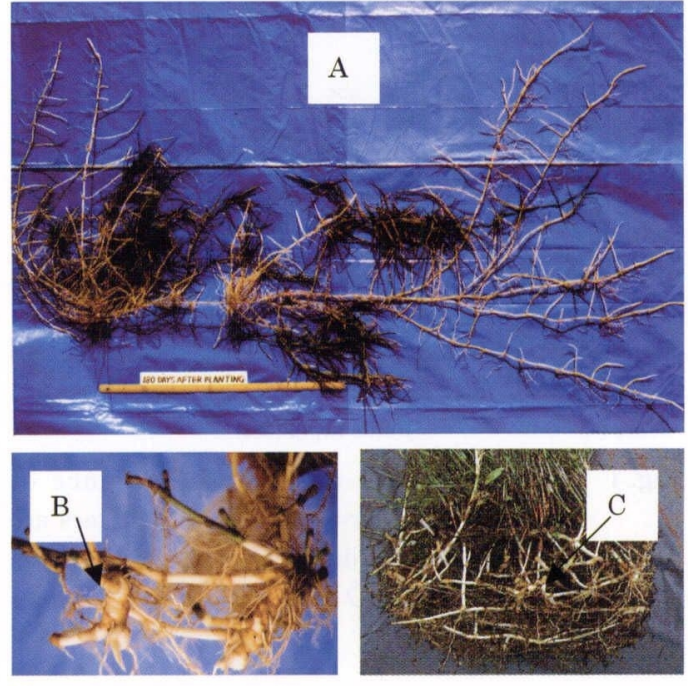

Fig. 6 Torpedograss plant showing shoots and rhizomes. A: a 180-day old torpedograss with $3 \mathrm{~m}$ long rhizome; $\mathrm{B}$ : ginger-like rhizome; $\mathrm{C}$ : rhizomes and roots showing a loose mat-like structure.

was needle-like, thereby enabling this rhizome to penetrate easily into deeper soil. Rhizome distribution in soil depended on the soil type and compactness. Rhizomes were distributed up to $15 \mathrm{~cm}$ in depth in golf courses and most rhizomes remained just below the turfgrass rootzone. In contrast, rhizomes were distributed up to $50 \mathrm{~cm}$ in cultivated fields, and most rhizomes remained within the upper $30 \mathrm{~cm}$ soil layer. The rhizome-internode length was 0.2 to $2.5 \mathrm{~cm}$ in golf courses due to soil compactness and walking and mowing effects, but was 3 to $6 \mathrm{~cm}$ in cultivated and fallow land. Some rhizomes were found to be rotten in golf courses and wasteland that had been infested for several years, but this was not found in cultivated fields infested for two or three years. Shoots were regularly mowed in golf courses, and, as a result, new shoots developed from the stem nodes and gingerlike rhizomes developed from this new shoot base. This characteristic was not found when torpedograss grew in cultivated fields. Each 
ginger-like rhizome was 2 to $30 \mathrm{~g}$ (Fig. 6), and remained dormant for several years.

Shoot and rhizome biomass of torpedograss increased rapidly when temperatures of 22 to $29^{\circ} \mathrm{C}$ prevailed. The plant required higher temperature for proper growth and development during the moderate and fast growth phases. Gray (pH 7.0 to 8.2 ) soil produced the highest biomass of torpedograss, followed by reddish soil ( $\mathrm{pH} 5.5$ to 6.8). Torpedograss also grew well in red soil ( $\mathrm{pH} 4.0$ to 5.0) and sand of seashore areas where most grass species failed. Most grass vegetation was damaged by typhoons and saline water, and none recovered except torpedograss.

Root crown developed from the submerged stem-nodes of torpedograss grown in standing water (12 cm deep). Spike-like tillers and sheath-like leaf blades were observed in water-treated plants. Higher shoot biomass and lower rhizome biomass were obtained from standing-water-treated plants than from untreated plants (Fig. 7). Standing water plus shoot removal of torpedograss caused rhizome death. Torpedograss survived well in standing water when the shoots remained above the water surface. Fresh rhizomes of torpedograss contained 54 to $66 \%$ water, and dried rhizomes regained up to $50 \%$ of their water when water supply was available.

Torpedograss grown for 90 days obtained a

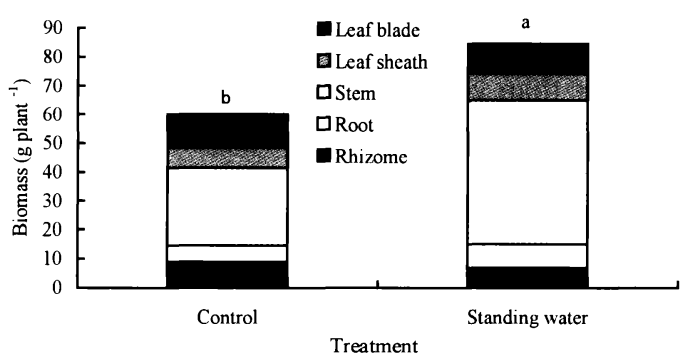

Fig. 7 Effect of standing water on biomass production of torpedograss. Bars with the different leters are significantly different at the $5 \%$ level, as determined by LSD test for total biomass.

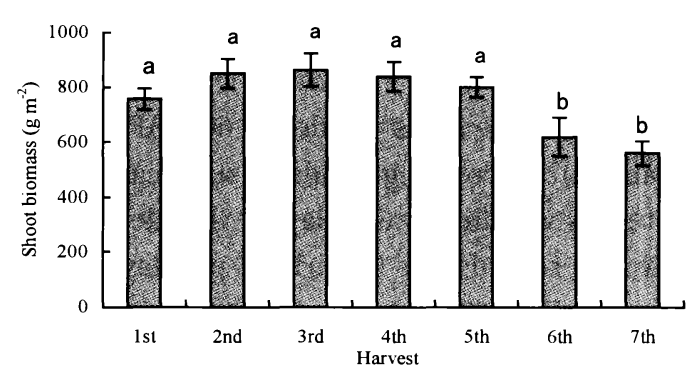

Fig. 8 Biomass production of torpedograss as a pasture plant. The plant was harveted on April 15 (1st), May 30 (2nd), July 15 (3rd), August 30 (4th), October 15 (5th), November 30 (6th) and January 15 (7th). Bars with the same letter are not significantly different at the $5 \%$ level, as determined by LSD test.

significantly higher biomass with 200 to $400 \mathrm{~kg}$ ai/ha $\mathrm{N}$ than obtained with the fertilizer was applied at a lower rate. The agronomic efficiency of $\mathrm{N}$ application decreased to 5 to 38 with the increase in $\mathrm{N}$ application to $400 \mathrm{~kg}$ ai/ha, which was less than half of the agronomic efficiency with the $200 \mathrm{~kg}$ ai $/$ ha $\mathrm{N}$. The agronomic efficiency of $\mathrm{N}$ was very low (5 to 22 ) during 60 DAP. Nitrogen application at a rate of $200 \mathrm{~kg}$ ai/ha was the most effective for torpedograss growth. Torpedograss was harvested six to seven times with a yield of 6 to 10 ton/ha each harvest per year by applying $\mathrm{N}$ fertilizer at 100 $\mathrm{kg}$ ai/ha after each harvest (Fig. 8).

\section{Mechanical and manual control strategies of torpdograss in sugarcane}

Moldboard plowing up to $50 \mathrm{~cm}$ depth followed by two cross-passes with a rototiller at a 40-day interval before sugarcane plantation damaged weed seedlings and rhizomes, and reduced torpedograss infestation. Burying deeper than $30 \mathrm{~cm}$ by deep plowing might effectively reduce emergence of this weed.

Torpeodograss reduced sugarcane yields by 65 to $80 \%$, and sugarcane reduced weed biomass by 25 to $56 \%$. In an artificially infested plant sugarcane (first season) field, no regrowth of 
torpedograss (TG) was observed when weeding was done 45 DAP; regrowth was observed, however, in the fields weeded at 60 DAP or later (Table 2). Decreasing yields of sugarcane were noted as weeding was delayed; this decreased rate was recorded as 0.9 to $1.5 \%$ per day during 45 to $90 \mathrm{DAP}$. In the ratoon sugarcane period, no regrowth of TG was observed in the fields weeded at $45 \mathrm{DAP}$, and these fields achieved a significantly higher yield than did the later weeded fields. Around 10 times greater TG biomass was recorded from the 60 DAP weeded fields in the ratoon sugarcane period than that in the plant sugarcane period. Ratoon sugarcane yield of 60 DAP or later weeded fields was half that of the weed-free or 45 DAP weeded field (Table 2). Torpedograss should be controlled within $45 \mathrm{DAP}$ in the plant sugarcane period to achieve lower weed infestation and to obtain a higher yield in both plant and ratoon sugarcane. Proper weed control in the first sugarcane season could result in increased ratoon yield for several seasons.

Table 2. Effects of weeding time on torpedograss control and sugarcane yield in plant sugarcane and ratoon sugarcane fields.

\begin{tabular}{|c|c|c|c|c|}
\hline \multirow{2}{*}{$\begin{array}{l}\text { Weeding } \\
\text { time (DAP) }\end{array}$} & \multicolumn{2}{|c|}{ Weed biomasss $\left(\mathrm{gm}^{-2}\right)$} & \multicolumn{2}{|c|}{ Sugarcane yield $\left(\mathrm{gm}^{-2}\right)$} \\
\hline & $\begin{array}{c}\text { Plant } \\
\text { sugarcane }\end{array}$ & $\begin{array}{c}\text { Ratoon } \\
\text { sugarcane }\end{array}$ & $\begin{array}{c}\text { Plant } \\
\text { sugarcane }\end{array}$ & $\begin{array}{c}\text { Ratoon } \\
\text { sugarcane }\end{array}$ \\
\hline $\mathrm{T}$ & $2257 \mathrm{a}$ & $3220 \mathrm{a}$ & $5787 a$ & $8267 a$ \\
\hline \multicolumn{5}{|l|}{ S } \\
\hline $\mathrm{W}(45)$ & $3 d$ & - & $5148 \mathrm{a}$ & $9719 a$ \\
\hline $\mathrm{W}(60)$ & $130 \mathrm{c}$ & $1242 \mathrm{bc}$ & 3993b & $4977 \mathrm{~b}$ \\
\hline $\mathrm{W}(90)$ & $300 \mathrm{bc}$ & $1159 c$ & $2952 b c$ & $4048 b$ \\
\hline $\mathrm{W}(120)$ & $512 b$ & $1321 b c$ & $2624 \mathrm{c}$ & $4825 \mathrm{~b}$ \\
\hline $\mathrm{NW}(0)$ & $570 \mathrm{~b}$ & $1840 \mathrm{~b}$ & $2347 c$ & $4116 b$ \\
\hline
\end{tabular}

DAP, days after planting; T, only torpedogrss; S, only sugarcane; W(45), weeding at 45 DAP; W(60), weeding at $60 \mathrm{DAP}$; $(90)$, weeding at $90 \mathrm{DAP}$; W(120), weeding at $120 \mathrm{DAP}$; NW(0), no weeding; -, torpedograss not found. Means with the same letter(s) within each column are not significantly different at the $5 \%$ level, as determined by LSD test.
Table 3. Efficacy of different herbicides on torpedograss shoot and rhizome. ${ }^{*}$

\begin{tabular}{lccc}
\hline Herbicide & $\begin{array}{c}\text { Rate } \\
\left(\mathrm{kg} \mathrm{ai} \mathrm{ha}^{-1}\right)\end{array}$ & $\begin{array}{c}\text { Shoot } \\
\text { control (\%) }\end{array}$ & $\begin{array}{c}\text { Rhizome } \\
\text { control (\%) }\end{array}$ \\
\hline Asulam & $2.0-4.0$ & $60-87$ & $90-95$ \\
Bialaphos & $1.5-3.0$ & $57-67$ & $25-72$ \\
Glufosinate & $1.5-3.0$ & $80-90$ & $49-100$ \\
Glyphosate & $1.5-3.0$ & $40-67$ & $40-92$ \\
Hexazinon & $5.0-10.0$ & $47-60$ & $48-100$ \\
\hline
\end{tabular}

${ }^{*}$ Data of the most effective herbicides among 27 were presented in this table.

$\# 0=$ no effect $\sim 100=$ complete killing.

\section{Chemical control strategies of torpedograss in sugarcane}

Twenty-seven different herbicides were tested to evaluate their herbicidal efficiency on torpedograss in a field. Among the tested herbicides, single applications of asulam (2.0 to $4.0 \mathrm{~kg}$ ai/ha), bialaphos (1.5 to $3.0 \mathrm{~kg} \mathrm{ai} / \mathrm{ha}$ ), glufosinate (1.5 to $3.0 \mathrm{~kg}$ ai/ha), glyphosate $(1.5$ to $3.0 \mathrm{~kg}$ ai/ha), and hexazinon (5.0 to $10.0 \mathrm{~kg}$ ai/ha) effectively controlled torpedograss shoots and rhizomes (Table 3 ).

Asulam at 2 to $4 \mathrm{~kg}$ ai/ha applied 20, 40, 60 or 80 DAP controlled $100 \%$ of torpedograss shoots in sugarcane (Table 4). Regrowth of torpedograss was not observed in pot experiments when asulam was applied within 40 DAP because no new rhizomes developed during this period. However, regrowth levels of $<25$ and $>75 \%$ were found in pot experiments when asulam was applied at 60 and 80 DAP because mature rhizome buds survived in a larger number than younger rhizome buds (Table 4). In a naturally infested field, asulam applied 20, 40,60 or 80 DAP resulted in regrowth levels of $>75,51$ to 75,1 to 25 or 26 to $50 \%$ (Table 4 ). Regrowth levels were the highest in the fields with asulam applied at 20 DAP because most of the existing rhizomes had not emerged from the soil during this period and were therefore not affected by the herbicide. Regrowth levels were the lowest in the fields with asulam applied 
Table 4. Effects of asulam application timing and rates on torpedograss control and sugarcane yield in pot and field experiments.

\begin{tabular}{|c|c|c|c|c|c|c|c|}
\hline \multirow{2}{*}{$\begin{array}{l}\text { Application } \\
\text { timing (DAP) }\end{array}$} & \multirow{2}{*}{$\begin{array}{c}\text { Rates } \\
\left(\mathrm{kg}^{2} \text { ai ha }{ }^{-1}\right)\end{array}$} & \multicolumn{2}{|c|}{ Torpedograss control (\%) } & \multicolumn{2}{|c|}{ Regrowth (\%) ${ }^{\dagger}$} & \multicolumn{2}{|c|}{ Sugarcane yield } \\
\hline & & Pot & Field & Pot & Field & Pot $\left(\mathrm{g} \mathrm{plant}^{-1}\right)$ & Field $\left(\mathrm{g} \mathrm{m}^{-2}\right)$ \\
\hline \multirow[t]{3}{*}{20} & 2.0 & 100 & 100 & Rnf & $>75$ & $1573 a$ & $1141 \mathrm{a}$ \\
\hline & 3.0 & 100 & 100 & Rnf & $>75$ & 973bcde & 1086a \\
\hline & 4.0 & 100 & - & Rnf & - & $487 \mathrm{f}$ & - \\
\hline \multirow[t]{3}{*}{40} & 2.0 & 100 & 100 & Rnf & $51-75$ & $1043 \mathrm{bcd}$ & $1175 \mathrm{a}$ \\
\hline & 3.0 & 100 & 100 & Rnf & $51-75$ & $1062 \mathrm{bc}$ & $1257 \mathrm{a}$ \\
\hline & 4.0 & 100 & - & Rnf & - & 988bcde & - \\
\hline \multirow[t]{3}{*}{60} & 2.0 & 100 & 100 & $<25$ & $<25$ & 957bcde & $1048 \mathrm{a}$ \\
\hline & 3.0 & 100 & 100 & $<25$ & $<25$ & 953bcde & $1003 \mathrm{ab}$ \\
\hline & 4.0 & 100 & - & $<25$ & - & $937 \mathrm{cde}$ & - \\
\hline \multirow[t]{3}{*}{80} & 2.0 & 100 & 100 & $>75$ & $26-50$ & $832 \mathrm{e}$ & $753 \mathrm{c}$ \\
\hline & 3.0 & 100 & 100 & $>75$ & $26-50$ & 853de & $765 \mathrm{bc}$ \\
\hline & 4.0 & 100 & - & $>75$ & - & $837 \mathrm{e}$ & - \\
\hline S (check) & & & - & & - & $1104 \mathrm{~b}$ & - \\
\hline $\mathrm{S}+\mathrm{T}$ (check) & Hna & 0 & - & 100 & - & $621 \mathrm{f}$ & - \\
\hline
\end{tabular}

$\mathrm{S}$, only sugarcane; $\mathrm{S}+\mathrm{T}$, sugarcane and torpedograss; \#, $0=$ no effect $\sim 100=$ complete killing; $\dagger$, regrowth $(\%)=($ Number of shoots emerging after herbicide application/Number of shoots at time of herbicide application) X 100; DAP, days after planting; Hna, herbicide not applied; -, experiment not conducted; Rnf, regrowth not found. Values with the same letter(s) within each column are not significantly different at the $5 \%$ level, as determined by LSD test.

60 DAP because most of the existing rhizomes completed emergence during this period and were killed by the herbicide. Furthermore, regrowth was higher in 80 DAP-applied fields than in 60-DAP applied fields because more new rhizomes developing within 80 DAP survived after asulam application.

Asulam at $4 \mathrm{~kg}$ ai/ha applied 20 DAP severely impacted growth and yield of sugarcane, while 2,3 and $4 \mathrm{~kg}$ ai/ha of asulam applied 40 DAP or later had no injurious effects (Table 4). The herbicide applied at 2 to $3 \mathrm{~kg}$ ai/ha within 60 DAP resulted in a remarkably higher sugarcane yield than that applied 80 DAP (Table 4).

Torpedograss could not be completely controlled with a single application of asulam in a naturally infested field. Asulam application (3 $\mathrm{kg}$ ai/ha) at a 70-day or more interval completely controlled above-ground shoots but not regrowth from rhizomes. Asulam at $3 \mathrm{~kg}$ ai/ha applied three times at 40-day intervals starting 40 days after land preparation provided excellent control of torpedograss in sugarcane fields (Fig. 9).

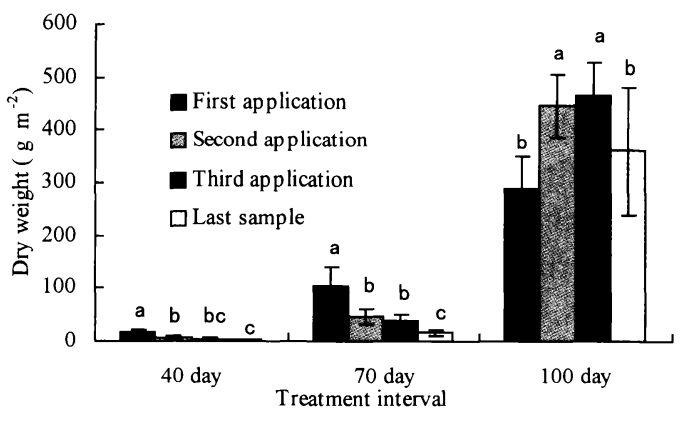

Fig. 9 Effect of application interval of asulam on dry weight production of torpedograss shoots. Bars with the same letter are not significantly different at the $5 \%$ level, as determined by LSD test.

\section{Torpedograss control in Turf}

Asulam at $4.00 \mathrm{~kg}$ ai $/ \mathrm{ha}$, flazasulfuron at $0.25 \mathrm{~kg}$ ai $/ \mathrm{ha}$, asulam at $4.00 \mathrm{~kg}$ ai $/$ ha plus flazasulfuron at $0.25 \mathrm{~kg}$ ai $/ \mathrm{ha}$, asulam at 4.00 $\mathrm{kg}$ ai/ha plus flazasulfuron at $0.10 \mathrm{~kg}$ ai $/ \mathrm{ha}$, asulam at $2.00 \mathrm{~kg}$ ai/ha plus flazasulfuron at $0.25 \mathrm{~kg}$ ai $/ \mathrm{ha}$, and asulam at $2.00 \mathrm{~kg}$ ai/ha plus flazasulfuron at $0.10 \mathrm{~kg}$ ai/ha were evaluated for torpedograss control in manilagrass (Zoysia 
matrella (L.) Merr.) turf (Table 5). Asulam and asulam plus flazasulfuron exhibited statistically similar efficacy in control of torpedograss shoots (100\%) and rhizome-buds (72-89\%). However, asulam plus flazasulfuron showed up to $15 \%$ higher efficacy in rhizome control than asulam applied alone. Asulam plus flazasulfuron combinations controlled torpedograss shoots seven days earlier, and resulted in a nonsignificant lower regrowth up to $33 \%$ compared to asulam alone. A slight yellowish injury (5.7-8.3\%) appeared on turfgrass for a few days, but it disappeared rapidly and the turfgrass became greener when asulam or asulam plus flazasulfuron was applied. All combinations of asulam plus flazasulfuron exhibited similar weed control efficacy. The lowest rate of asulm at $2 \mathrm{~kg}$ ai/ha plus flazasulfuron at $0.1 \mathrm{~kg}$ ai/ha resulted in the lowest turf injury (5.7\%) (Table 5).

Lengths of stem internodes of torpedograssshoots from soil surface to turfgrass surface were 0.2 to $2.5 \mathrm{~cm}$, and one stem had 5 to 10 internodes, so the herbicide had to pass many nodes. It was assumed that herbicide could not reach each rhizome bud, which resulted in higher rhizome survival and regrowth in golf courses. However, rhizome internodes were longer in crop fields and herbicides had to pass fewer nodes. As a result, herbicide could reach the end of rhizomes, and there was very little regrowth.

Rhizomes of torpedograss were aged and had many ginger-like rhizomes in golf courses, and these were not completely affected by herbicides. Rhizomes remained undisturbed in golf courses, which probably resulted in lower control rates of rhizome than in crop fields. In addition, stem-rhizomes and creeping-rhizomes developed many ginger-like rhizomes, which were established individually. As a result, herbicides did not pass to rhizomes that did not develop shoots. Around 28\% rhizome-buds (200 buds per $\mathrm{m}^{2}$ ) survived after herbicide application and further infested the golf course severely.

A single application of asulam at $2 \mathrm{~kg}$ ai/ha plus flazasulfuron at $0.1 \mathrm{~kg}$ ai $/$ ha could not control torpedograss rhizomes completely in golf courses. Sequential applications of the herbicide at around a 45-day interval should be required until torpedograss regrowth is found in golf course. Herbicides should be applied at least in the 4- to 5-leaf stage (around 30 days after turf mowing) of torpedograss, and turfgrass should be mowed at least 15 days after herbicide application for effective control. Herbicides should be applied before 10 a.m. for better control of torpedograss. Rainfall within five hours after herbicide application reduces

Table 5. Effects of asulam, flazasulfuron or asulam plus flazasulfuron on torpedograss control and turfgrass.

\begin{tabular}{|c|c|c|c|c|c|c|c|}
\hline \multirow{2}{*}{$\begin{array}{l}\text { Herbicide } \\
\text { treatment }\end{array}$} & \multirow{2}{*}{$\begin{array}{c}\text { Rate } \\
\text { (kg ai/ha) }\end{array}$} & \multicolumn{2}{|c|}{ Shoot control (\%) ${ }^{\#}$} & \multicolumn{2}{|c|}{ Rhizome control (\%) } & \multirow{2}{*}{$\begin{array}{l}\text { Torpedograss } \\
\text { regrowth }(\%)^{\dagger}\end{array}$} & \multirow{2}{*}{$\begin{array}{c}\text { Turf } \\
\text { injury (\%) }\end{array}$} \\
\hline & & 28DAT & 35DAT & $\mathrm{CR}$ & GR & & \\
\hline Asulam & 4.00 & $92 \pm 2 b$ & $100 \pm 0 \mathrm{a}$ & $72 \pm 4 a$ & $73 \pm 4 a$ & $9 \pm 2 a$ & $8.3 \pm 2.4 \mathrm{a}$ \\
\hline Flazasulfuron & 0.25 & $0 \pm 0 \mathrm{c}$ & $0 \pm 0 \mathrm{~b}$ & - & - & - & - \\
\hline Asulam + flazasulfuron & $4.00+0.25$ & $100 \pm 0 a$ & $100 \pm 0 \mathrm{a}$ & $83 \pm 7 a$ & $80 \pm 3 a$ & $6 \pm 2 a$ & $6.7 \pm 2.4 \mathrm{a}$ \\
\hline Asulam + flazasulfuron & $4.00+0.10$ & $100 \pm 0 \mathrm{a}$ & $100 \pm 0 \mathrm{a}$ & $79 \pm 5 a$ & $78 \pm 5 a$ & $7 \pm 2 a$ & $6.7 \pm 2.4 \mathrm{a}$ \\
\hline Asulam + flazasulfuron & $2.00+0.25$ & $100 \pm 0 \mathrm{a}$ & $100 \pm 0 \mathrm{a}$ & $76 \pm 4 a$ & $76 \pm 1 \mathrm{a}$ & $7 \pm 2 \mathrm{a}$ & $6.7 \pm 2.4 \mathrm{a}$ \\
\hline Asulam + flazasulfuron & $2.00+0.10$ & $100 \pm 0 \mathrm{a}$ & $100 \pm 0 \mathrm{a}$ & $81 \pm 3 a$ & $81 \pm 3 a$ & $6 \pm 2 a$ & $5.7 \pm 2.4 \mathrm{a}$ \\
\hline
\end{tabular}

$\#, 0=$ no effect $\sim 100=$ complete killing; $\dagger$, regrowth $(\%)=($ Number of shoots emerging after herbicide application/ Number of shoots at time of herbicide application) X 100; $\ddagger$, injury level is expressed as percent shoot discoloration compared with the untreated check. DAT, days after treatment; CR, creeping rhizome; GR, ginger-like rhizome; -, data not recorded. Values with the same letter within each column are not significantly different at the $5 \%$ level, as determined by LSD test. 
herbicidal efficacy.

\section{Possible uses}

Pasture: Torpedograss could provide a good pasturage because it grows throughout the year and it is palatable for horses, cattle, and goats. Torpedograss is the best grass species for sandy soil, acidic soil, alkaline soil, infertile soil, wet conditions, and standing water conditions, where most grasses fail. This grass can be harvested six to seven times with a yield of 6 to 10 ton/ha each harvest in a year (Fig. 8).

Soil erosion control: Torpedograss could be the best natural resource for soil erosion control because it maintains high shoot densities throughout the year, which protects soil from rainfall and strong winds. Huge rhizomes and roots make (fresh, 2 to $5 \mathrm{~kg} / \mathrm{m}^{2}$ ) a loose matlike structure up to $50 \mathrm{~cm}$ deep and hold the soil compactly. Root and rhizome systems can prevent pond and dam edges from eroding (Fig. $6)$.

Evergreen vegetation: Torpedograss has an extraordinary ability to withstand highly adverse climatic and edaphic conditions. Torpedograss damaged by typhoons and saline water reestablished normal vegetation within one month. Torpedograss could be used as a cover crop in forests and orchards because it grows in shade. This plant uptakes water from $150 \mathrm{~cm}$ soil layer and rhizomes hold water, so it can be grown in arid, semiarid and desert areas where rainfall is scarce.

Extraordinary gene resource: Torpedograss can grow with a high soil $\mathrm{pH}$ range of 4 to 10 and a wide temperature range of 15 to $50^{\circ} \mathrm{C}$. It grows on seashores and in mountain areas, and it is resistant to drought, standing water and high salt concentrations.

\section{Conclusion}

Torpedograss grows well from seashore to elevations of $2000 \mathrm{~m}$ in diverse climatic and edaphic conditions such as high salt concentration, shallow standing water, drought, shade, sunny condition, sandy soil, clay soil, acidic soil and alkaline soil. Torpedograss is very important for protecting soil erosion, maintaining green vegetation and providing pasture. Aboveground shoots and rhizomes of torpedograss increase slowly until 50 days after planting (DAP), thereafter, they increase geometrically over time. Three growth phases were identified: establishment phase (up to 70 DAP), moderate growth phase (70 to $110 \mathrm{DAP}$ ) and fast growth phase (110 DAP to last harvest). Rhizome has been classified as creeping rhizome and gingerlike rhizome. Asulam at 2.0 to $3.0 \mathrm{~kg}$ ai/ha should be applied at 45-day intervals starting 45 days after sugarcane planting for better control of torpedograss. Asulam at $2.0 \mathrm{~kg}$ ai/ha plus flazasulfuron at $0.10 \mathrm{~kg}$ ai/ha should be applied at 45-day intervals until the regrowth of torpedograss is found in manilagrass turf.

\section{Acknowledgements}

All praises are due to Almighty Allah (SWT) who enabled me to receive this award. I would like to express my deepest gratitude to my reverend professor Yukio Ishimine, University of the Ryukyus for his scholastic and sincere supervision in this research work. Special thanks are due to Prof. S. Murayama and Associate Prof. H. Akamine of the University of the Ryukyus, and Associate Prof. H. Kuramochi of Utsunomiya University for their supervision in this study. I am grateful to Prof. N. Ichizen, Prof. Y. Takeuchi and Prof. M. Konnai of Utsunomiya University, Dr. K. Ito of JIRCAS, Prof. M. Nemoto of Tokyo University of Agriculture, and Prof. H. Shibayama of Saga University for their kind supports in all aspects of this award. I would like to thank all professors and members of the University of the Ryukyus, Kagoshima University, Sher-e-Bangla Agricultural University, WSSJ, Urasoe Rotary Club and Monbusho for their kind cooperation 
in this study. I would like to express my heartfelt gratitude to the president, Singoro Matsuura of Manda Fermentation Co., Ltd., for providing me financial support during this study. Many thanks are due to my parents, brothers, sisters, relatives, son (Rakin Al-Imad Hossain), daughter (Nimat Hossain Rafa) and wife (Mst. Rokshana Khatun) for their life-long support in all aspects of my life. This award is dedicated to my dearest father, Alhaj Azahar Ali Sheikh, who passed away on November 28, 2004.

\section{References}

1. Hossain M. A., Y. Ishimine, H. Akamine and S. Murayama, 1996. Growth and development characteristics of torpedograss (Panicum repens $\mathrm{L}$.) in Okinawa island, southern Japan. Weed Research, Japan, vol. 41(4), 323-331.

2. Hossain M. A., Y. Ishimine, H. Kuramochi, H. Akamine, S. Murayama and M. Konnai, 1997. Efficacy of post-emergence herbicides on torpedograss (Panicum repens L.). J. Weed Sci. Tech., vol. 42(3), 197-205.

3. Hossain M. A., Y. Ishimine, H. Akamine, S. Murayama and H. Kuramochi, 1997. Growth characteristics, emergence pattern and control of torpedograss (Panicum repens L.) in sugarcane. 16th APWSS Conf. Kuala Lumpur, Malaysia, Proceedings, 310-313.

4. Hossain M. A., Y. Ishimine, K. Taniguchi, M. Konnai, H. Akamine, H. Kuramochi and S. Murayama, 1998. Effects of asulam on sugarcane and torpedograss (Panicum repens L.). J. Weed Sci. Tech., vol. 43(1), 10-19.

5. Hossain M. A., I. Nakamura, Y. Ishimine, S. Murayama, H. Shibayama and E. Tsuzuki, 1998. Interaction between sugarcane and torpedograss (Panicum repens L.) densities. Sci. Bull. Fac. Agr. Univ. Ryukyus, Vol. 45, 167-183.

6. Hossain M. A., Y. Ishimine and S. Murayama, 1998. Torpedograss (Panicum repens L.) growth characteristics and control strategy. Agric. Expt. Farm Memory, Fac. Agric. Univ. Ryukyus, 40th Year Anniversary, pp. 86-109.

7. Hossain M. A., Y. Ishimine, H. Akamine, S. Murayama and M. Nemoto, 1999. Critical period for torpedograss (Panicum repens L.) control in plant sugarcane fields on Okinawa island, southern Japan. J. Weed Sci. Tech., vol. 44(1), 9-18.

8. Hossain M. A., Y. Ishimine, H. Akamine, S. Murayama, S. M. M. Uddin and K. Kuniyoshi, 1999. Effect of burial depth on emergence of Panicum repens. Weed Sci., Vol. 47(6), 651-656.

9. Hossain M. A., S. Matsuura, I. Nakamura, M. Doi and Y. Ishimine, 2000. Studies on application methods of Manda 31 for turmeric (Curcuma spp.) cultivation. Sci. Bull. Fac. Agr. Univ. Ryukyus, Vol. 47, 137-144.

10. Hossain M. A., H. Kuramochi, Y. Ishimine and H. Akamine, 2001. Application timing of asulam for torpedograss (Panicum repens L.) control in sugarcane in Okinawa island. Weed Biol. Manag. Vol. 1(2), 108-114.

11. Hossain M. A., H. Akamine, I. Nakamura, Y. Ishimine and $\mathrm{H}$. Kuramochi, 2001. Influence of temperature levels and planting time on sprouting of rhizome-bud and biomass production of torpedograss (Panicum repens L.) in Okinawa island, southern Japan. Weed Biol. Manag. Vol. 1 (3), 164-169.

12. Hossain M. A., Y. Ishimine, H. Kuramochi and H. Akamine, 2002. Interval between sequential applications of asulam for regrowth control of torpedograss (Panicum repens L.). Weed Biol. Manag. Vol. 2(2), 92-97.

13. Hossain M. A., Y. Ishimine, H. Kuramochi and H. Akamine, 2002. Effect of standing water and shoot removal plus standing water regimes on growth, regrowth and biomass production of torpedograss (Panicum repens L.). Weed Biol. Manag. Vol. 2(3), 157-162.

14. Hossain M. A., S. Matsuura, M. Doi and Y. Ishimine, 2002. Growth and yield of turmeric (Curcuma spp.) and sweet bell pepper (Capsicum annum L.) as influenced by Manda-compost. Sci. Bull. Fac. Agr. Univ. Ryukyus, Vol. 49, 205-212.

15. Hossain M. A., S. Matsuura, M. Doi and Y. Ishimine, 2003. Effect of Manda 31 on growth of corn (Zea mays). Sci. Bull. Fac. Agr. Univ. Ryukyus, Vol. 50, 171-175.

16. Hossain M. A., Y. Ishimine, H. Akamine and H. Kuramochi, 2004. Effect of nitrogen fertilizer application on growth, biomass production and $\mathrm{N}$-uptake of torpedograss (Panicum repens L.). Weed Biol. Manag. Vol 4(2), 86-94.

17. Hossain M. A., 2004. Biology, ecology and possible uses of torpedograss (Panicum repens L.). Japanese 
Society of Turfgrass Science Symposium, Okinawa, Japan, Proceedings, 33,13-15.

18. Hossain M. A., S. Matsuura, M. Doi and Y. Ishimine, 2004. Damage recovery, growth and yield of turmeric (Curcuma spp.) plant with manda 31 application after typhoon occurrence. Sci. Bull. Fac. Agr. Univ. Ryukyus, Vol. 51,145-149.

19. Hossain M. A., Y. Ishimine, H. Akamine and K. Motomura, 2005. Effects of seed rhizome size on growth and yield of turmeric (Curcuma Longa L.). Plant Prod. Sci. Vol. 8(1), 86-94.

20. Hossain M. A., Y. Ishimine, K. Motomura and H. Akamine, 2005. Effects of planting pattern and planting distance on growth and yield of turmeric (Curcuma Longa L.). Plant Prod. Sci. Vol. 8(1), 95-105.

21. Hossain M. A. and Y. Ishimine, 2005. Growth, yield and quality of turmeric (Curcuma Longa L.) cultivated in dark-red soil, gray soil and red soil. Plant Prod. Sci. Vol. 8 (3), (in press).

22. Hossain M. A., H. Akamine, H. Kuramochi, Y. Ishimine and H. Higa, 2005. Torpedograss (Panicum repens L.) control in manilagrass (Zoysia matrella (L.) Merr.) turf with asulam plus flazasulfuron. Weed Biol. Manag. (Processing).

23. Ishimine Y., M. A. Hossain, K. Motomura, H. Akamine, S. Murayama and Z. Koja, 1993. Physiological and ecological characteristics of sugarcane field weeds in the Ryukyu islands. 13. Effects of weeding time of torpedograss (Panicum repens L.) on early stage of sugarcane growth. Sci. Bull. Coll. Agr. Univ. Ryukyus, Vol. 40, 143-152.

24. Ishimine Y., M. A. Hossain, K. Motomura, H. Akamine, S. Murayama and S. M. M. Uddin, 1994. Comparative study of sett planting and settling transplanting system of sugarcane. Sci. Bull. Coll. Agr. Univ. Ryukyus, Vol. 41, 319-326.

25. Ishimine Y., M. A. Hossain, K. Motomura, H. Akamine, S. Murayama and S. M. M. Uddin, 1994. Physiological and Ecological Studies on Control of Perennial Weed Panicum repens L. 1. Effect of three different types of Okinawan soil on growth of torpedograss (Panicum repens L.). Sci. Bull. Coll. Agr. Univ. Ryukyus, Vol. 41, 327-333.

26. Ishimine Y., M. A. Hossain, Y. Ishimine and S. Murayama, 2003. Optimal planting depth for turmeric (Curcuma longa L.) cultivation in dark red soil in Okinawa island, southern Japan. Plant Prod. Sci. Vol. 6 (1), 83-89.

27. Ishimine Y., M. A. Hossain, K. Motomura, H. Akamine and T. Hirayama, 2004. Effect of temperature levels and planting date on emergence, growth and yield of turmeric (Curcuma longa L) in Okinawa prefecture, southern Japan. Jpn. J. Trop. Agr. 48 (1), 10-16.

28. Ishimine Y., S. Matsuura, M. A. Hossain and I. Nakamura, 1999. Influence of fermented natural plant concentrate (Manda 31) on growth and yield of turmeric (Curcuma spp.). Sci. Bull. Fac. Agr. Univ. Ryukyus, Vol. 46, 161-168.

29. Matin, M. A., M. A. Hossain, K. Oya, A. H. M. D. Hossain, M. K. Rahman. and S. M. M. Uddin, 1993. Critical period for weed management in sugarcane field. Journal of Okinawa Agriculture, vol. 28(1), 22-27.

30. Nakamura I., S. Matsuura, M. A. Hossain, M. Doi and Y. Ishimine, 2001. Efficacy of Manda 31 with fertilizer rates on growth and yield of turmeric (Curcuma spp.). Sci. Bull. Fac. Agr. Univ. Ryukyus, Vol. 48, 145-152. 